\title{
PERBEDAAN PENGETAHUAN GIZI, SIKAP DAN ASUPAN ZAT GIZI PADA DEWASA AWAL (MAHASISWI LPP GRAHA WISATA DAN SASTRA INGGRIS UNIVERSITAS DIPONEGORO SEMARANG)
}

\author{
Rizki Putri Anjani, Apoina Kartini \\ Program Studi Ilmu Gizi Fakultas Kedokteran Universitas Diponegoro \\ Jl.Dr.Sutomo No.14, Semarang, Telp (024) 8453708, Email : gizifk@ undip.ac.id
}

\begin{abstract}
Backgrounds : Nutrition in early adulthood is needed to promote health. In early adulthood, particularly female, there are more attentions to physical appearance. Knowledge, attitude influenced nutrient intake and the practice. The purpose of this study is to find out difference in nutritional knowledge, attitude and nutrient intake in early adulthood.

Methods : Cross-sectional study of 50 female students in LPP Graha Wisata and English Literature of Diponegoro University Semarang. Sample was collected using simple random sampling method. The data collected were identity data measured using questionnaire, data about body weight and height obtain using measurement of body weight and height, intake of energy, fat, protein, liquid and fiber measured using three-days food recall form, nutritional knowledge and attitude measured using questionnaire about nutritional knowledge and attitude. Data analyses for energy, protein, fat, and liquid intake using independent t-test whereas for fiber intake, nutritional knowledge and attitude using Mann-Whitney test.

Result : The nutritional knowledge in female students of early adulthood are categorized as inadequate (58\%). The energy intake are categorized as deficit (48\%). The fat intake are categorized as good (40\%). The protein intake are categorized as deficit (70\%). The liquid intake are categorized as deficit (90\%). The fiber intake are categorized as deficit (100\%). There are no difference in intake of energy, fat, protein, fiber and attitude $(p=0,771 ; p=0,628$; $p=0,778 ; p=0,923 ; p=0,344$ repectively), but there are difference in nutritional knowledge and in liquid intake between the two groups ( $p=0,048 ; p=0,000$ respectively).

Conclusion: There are no differences in intake of energy, fat, protein, fiber and attitude, but the are differences in nutritional knowledge and intake of liquid between female students of LPP Graha Wisata and female students of English Literature of Diponegoro University Semarang.
\end{abstract}

Keywords : Early adulthood, energy, protein, fat, liquid, fiber, nutritional knowledge, attitude.

\begin{abstract}
ABSTRAK
Latar Belakang : Gizi pada dewasa awal lebih dibutuhkan untuk mencegah penyakit dan meningkatkan kesehatan. Perubahan yang terjadi pada masa ini salah satunya adalah perubahan komposisi tubuh dan kebutuhan energi. Dewasa awal terutama wanita mempunyai kepedulian yang lebih besar terhadap masalah penampilan fisik. Pengetahuan gizi membuat mereka lebih mengetahui tentang asupan zat gizi dan prakteknya. Penelitian ini bertujuan untuk mengetahui perbedaan pengetahuan gizi, sikap dan asupan zat gizi pada dewasa awal.

Metode : Studi cross sectional pada 50 mahasiswi di LPP Graha Wisata dan Sastra Inggris Universitas Diponegoro Semarang. Sampel diambil secara simple random sampling. Data yang dikumpulkan adalah data identitas yang diukur dengan menggunakan kuesioner, data berat badan dan tinggi badan diukur dengan pengukuran berat badan dan tinggi badan, asupan energi, lemak, protein, cairan dan serat diukur dengan menggunakan formulir food recall selama tiga hari, pengetahuan gizi dan sikap diukur dengan menggunakan kuesioner pengetahuan gizi dan sikap. Analisis data untuk asupan zat gizi dengan uji independent t-test dan untuk pengetahuan gizi dan sikap dengan uji mann whitney dengan bantuan SPSS 17.0 for windows.

Hasil : Pengetahuan gizi dewasa awal termasuk kategori kurang. Asupan energi kategori defisit (48\%). Asupan lemak kategori baik (40\%). Asupan protein kategori defisit (70\%). Asupan cairan kategori defisit (90\%). Asupan serat kategori defisit (100\%). Tidak terdapat perbedaan asupan energi, lemak, protein, serat dan sikap ( $p=0,771$; $p=0,628 ; p=0,778 ; p=0,923 ; 0,344)$, tetapi ada perbedaan pengetahuan gizi dan asupan cairan pada kedua kelompok $(p=0,048$ dan $p=0,000)$.

Kesimpulan : Tidak terdapat perbedaan asupan energi, lemak, protein, serat dan sikap, tetapi ada perbedaan pengetahuan gizi dan asupan cairan antara mahasiswi LPP Graha Wisata dan Sastra Inggris Universitas Diponegoro Semarang.
\end{abstract}

Kata Kunci : dewasa awal, energi, protein, lemak, cairan, serat, pengetahuan gizi, sikap 


\section{PENDAHULUAN}

Pada masa dewasa zat gizi lebih dibutuhkan untuk mencegah penyakit dan meningkatkan kesehatan. ${ }^{1}$ Individu sering kali mulai merasa sadar tentang arti kesehatan tubuhnya ketika ia sedang mengalami sakit, tak terkecuali untuk orang yang memasuki masa dewasa muda. Dewasa muda adalah mereka yang berusia 19-24 tahun, dimana seseorang sedang mengalami peralihan dari masa remaja untuk memasuki masa tua. ${ }^{2}$

Perubahan yang terjadi pada masa ini salah satunya adalah perubahan komposisi tubuh dan kebutuhan energi. ${ }^{3}$ Adanya perubahan komposisi tubuh menyebabkan kebutuhan akan zat gizi meningkat. Asupan zat gizi tertentu yang tidak adekuat dan berlebih atau tidak seimbang dapat menyebabkan kondisi kesehatan yang buruk. ${ }^{4}$

Seseorang memiliki asupan zat gizi yang adekuat atau tidak, tergantung dari perilaku makan orang tersebut. ${ }^{5}$ Berdasarkan data $A D A$ (The American Dietetic Assosiation), asupan gizi dewasa meningkat dari tahun 2000 sebanyak $10 \%$ menjadi $38 \%$ pada tahun 2002 , ini dikarenakan faktor gaya hidup sehingga mempengaruhi perilaku makan individu tersebut. ${ }^{6}$

Departemen Kesehatan Amerika Serikat dan Pelayanan Kesehatan (DHHS) tahun 2010, mengakui pentingnya faktor gaya hidup dalam mencapai tujuan kesehatan dan meningkatkan kualitas hidup sehat orang Amerika. Faktor gaya hidup dapat mempengaruhi tingkah laku seseorang termasuk perilaku makan. ${ }^{1}$

Manusia membutuhkan asupan makanan yang bergizi untuk mempertahankan hidup guna menunjang pertumbuhan dan melakukan aktivitas harian. Usia, jenis kelamin, status kesehatan, pengetahuan, pendapatan, agama dan budaya merupakan faktor-faktor yang mempengaruhi asupan makan seseorang. ${ }^{7,8}$ Asupan makan harus sesuai dengan kebutuhan gizi seseorang, bila tidak terjadi kesesuaian antara makanan yang dikonsumsi dengan kebutuhan gizi seseorang, akan menimbulkan masalah kesehatan. ${ }^{9}$

Kebiasaan makan yang baik yang diberlakukan mulai dari awal kehidupan akan meningkatkan kualitas kesehatan pada masa dewasa. ${ }^{3}$ Penelitian yang dilakukan terhadap mahasiswa UNDIP pada tahun 2010 menyebutkan bahwa tingkat asupan energi 60,5\% tergolong defisiensi tingkat berat jika dibandingkan dengan Angka Kecukupan Gizi (AKG). Hal ini dipengaruhi oleh faktor body image ${ }^{10}$ dan faktor ekonomi serta akses terhadap makanan. ${ }^{11}$
Pengetahuan merupakan salah satu faktor yang mempengaruhi asupan makan seseorang. ${ }^{12}$ Pengetahuan dipengaruhi oleh beberapa faktor antara lain pendidikan, media massa, sosial budaya, ekonomi, lingkungan dan pengalaman. ${ }^{13}$ Sikap dan perilaku dalam memilih makanan secara tidak langsung dipengaruhi oleh tingkat pengetahuan gizi seseorang, yang menentukan mudah tidaknya seseorang memahami manfaat kandungan gizi dari makanan yang dikonsumsi. ${ }^{14}$ Pengetahuan gizi yang baik diharapkan mempengaruhi konsumsi makanan yang baik. Pengetahuan gizi juga mempunyai peranan yang sangat penting dalam pembentukan kebiasaan makan seseorang. ${ }^{15,16}$

Pengamatan awal yang dilakukan terhadap mahasiswi LPP Graha Wisata Semarang dan mahasiswi Program Studi Sastra Inggris Undip menunjukkan bahwa pada waktu kuliah mahasiswi LPP Graha Wisata Semarang mengenakan pakaian seragam dan sangat memperhatikan penampilan, sedangkan mahasiswi Program Studi Sastra Inggris Universitas Diponegoro Semarang tidak diharuskan mengenakan seragam. Mahasiswi LPP Graha Wisata Semarang dan mahasiswi Sastra Inggris Universitas Diponegoro Semarang tidak mendapatkan pendidikan mengenai ilmu gizi pada perkuliahan. Berdasarkan karakteristik dan latar belakang tersebut, peneliti akan melakukan penelitian untuk mengetahui perbedaan pengetahuan gizi, sikap dan asupan zat gizi pada dewasa awal, studi kasus pada mahasiswi LPP Graha Wisata Semarang dan mahasiswi Program Studi Sastra Inggris Universitas Diponegoro Semarang.

\section{METODE}

Penelitian dilaksanakan di kampus LPP Graha Wisata Semarang dan Fakultas Ilmu Budaya Universitas Diponegoro Program Studi Sastra Inggris. Pengambilan data dilakukan pada bulan Februari dan Maret 2012. Penelitian ini termasuk dalam lingkup keilmuan gizi masyarakat dan merupakan studi observasional dengan desain cross sectional.

Sampel penelitian diambil dengan cara simple random sampling, yaitu dengan dilakukan survey dahulu kemudian dipilih yang sesuai dengan kriteria penelitian. Berdasarkan hasil survey, sebanyak 55 sampel, 28 sampel berada di LPP Graha Wisata dan 27 sampel terdapat di Sastra Inggris Universitas Diponegoro yang sesuai dengan kriteria yang dibutuhkan. Kemudian masing-masing kampus diambil 25 subyek 
sehingga jumlah keseluruhan 50 sampel. Kriteria inklusi : bersedia menjadi sampel, mahasiswi usia 18-20 tahun, tidak sedang sakit, tidak sedang puasa, tidak sedang menjalankan program diet tertentu.

Variabel yang diteliti meliputi pengetahuan gizi, sikap dan asupan zat gizi. Pengetahuan gizi yang dimaksud dalam penelitian ini adalah ilmu tentang gizi yang diketahui subyek, meliputi energi, protein, lemak, serat dan cairan. Pengukuran dilakukan dengan angket. Pertanyaan berbentuk correct-answer multiple choice, skor satu (1) untuk jawaban benar dan nol (0) untuk jawaban yang salah. Pengetahuan gizi dikategorikan baik ( $>80 \%$ jawaban benar ), cukup ( $60-80 \%$ jawaban benar ), dan kurang ( $<60 \%$ jawaban benar $).{ }^{17}$ Sikap adalah cara pemahaman individu terhadap makanan atau asupan zat gizi yang diwujudkan melalui suatu tindakan. Pengukuran dilakukan dengan pengisian angket tentang sikap. Pertanyaan berbentuk best-answer multiple choice. Penilaian menggunakan skala Likert yaitu skor 5 apabila jawaban sangat setuju, skor 4 apabila jawaban setuju, skor 3 bila jawaban tidak tahu, skor 2 bila jawaban tidak setuju, dan skor 1 bila jawaban sangat tidak setuju. Responden dikatakan mempunyai sikap tidak mendukung asupan makan yang bergizi bila jawaban yang diberikan < 49,9 dan dikatakan mendukung asupan makan yang bergizi bila jawaban yang diberikan $\geq 49,9 .{ }^{18}$ Angket pengetahuan gizi dan sikap yang digunakan pada penelitian ini telah diujicoba di lapangan dan dilakukan uji validitas dan reliabilitasnya dengan Alpha Cronbach sebesar 0,754 ( angket pengetahuan ) dan 0,881 ( angket sikap ). Asupan zat gizi adalah jumlah rerata asupan energi, lemak, protein, serat dan cairan yang dikonsumsi selama tiga hari kemudian dihitung rata-rata per hari. Asupan zat gizi diukur dengan formulir food recall $3 \times 24$ jam. Data yang diperoleh (ukuran rumah tangga) dikonversikan ke dalam satuan gram kemudian dihitung nilainya. Jumlah asupan energi, protein, lemak, cairan dan serat dibandingkan dengan kebutuhan zat gizi sehari setiap individu dan dikategorikan menjadi baik : 100-120\%, sedang: 80-99\%, kurang: 7080\%, defisit: $<70 \%$. $^{17}$

Pengolahan dan analisis data dilakukan dengan menggunakan program Computer for Window. Analisis data univariat digunakan untuk mendeskripsikan masing-masing variabel. Analisis bivariat menggunakan independent sample t-test untuk menganalisis perbedaan asupan energi, lemak, protein dan cairan, mann whitney untuk menganalisis perbedaan pengetahuan gizi, sikap dan asupan serat.

\section{HASIL \\ Karakteristik Sampel}

Tabel 1. Karakteristik Sampel Penelitian

\begin{tabular}{cccc}
\hline Karakteristik & $\begin{array}{c}\text { Total } \\
(\mathrm{n}=50)\end{array}$ & $\begin{array}{c}\text { LPP Graha Wisata } \\
(\mathrm{n}=25)\end{array}$ & $\begin{array}{c}\text { Sastra Inggris } \\
(\mathrm{n}=25)\end{array}$ \\
\hline Umur (tahun) & $19,3 \pm 0,5$ & $19,2 \pm 0,4$ & $19,4 \pm 0,5$ \\
Berat Badan $(\mathrm{kg})$ & $49,2 \pm 7,8$ & $45,9 \pm 5,4$ & $52,5 \pm 1,7$ \\
Tinggi Badan $(\mathrm{cm})$ & $156,9 \pm 6,6$ & $153,8 \pm 6,3$ & $159,9 \pm 1,1$ \\
IMT $\left(\mathrm{kg} / \mathrm{m}^{2}\right)$ & $19,9 \pm 2,7$ & $19,4 \pm 2,2$ & $20,5 \pm 3,1$ \\
\hline
\end{tabular}

Kisaran IMT sampel di LPP Graha Wisata Semarang adalah $16 \mathrm{~kg} / \mathrm{m}^{2}-25,53 \mathrm{~kg} / \mathrm{m}^{2}$, sedangkan sampel di Sastra Inggris Undip adalah $16,3 \mathrm{~kg} / \mathrm{m}^{2}-28,44 \mathrm{~kg} / \mathrm{m}^{2}$. Sampel dengan nilai
IMT paling tinggi berada di Sastra Inggris Undip. Jumlah sampel yang memiliki status gizi normal lebih banyak terdapat di Sastra Inggris Undip dibanding di LPP Graha Wisata Semarang.

Table 2. Status Gizi Sampel Penelitian

\begin{tabular}{cccc}
\hline Status Gizi & $\begin{array}{c}\text { Total } \\
(\mathrm{n}=50)\end{array}$ & $\begin{array}{c}\text { LPP Graha Wisata } \\
(\mathrm{n}=25)\end{array}$ & $\begin{array}{c}\text { Sastra Inggris } \\
(\mathrm{n}=25)\end{array}$ \\
\hline Normal $(18,5-$ & $21(62 \%)$ & $14(56 \%)$ & $17(68 \%)$ \\
$22,9)$ & & & \\
Kurang $(<18,5)$ & $15(30 \%)$ & $9(36 \%)$ & $6(24 \%)$ \\
Lebih $(>22,9)$ & $4(8 \%)$ & $2(8 \%)$ & $2(8 \%)$ \\
\hline
\end{tabular}




\section{Pengetahuan Gizi}

Jawaban dari pertanyaan tentang pengetahuan gizi masih banyak yang salah. Terdapat 5 pertanyaan yang dijawab salah oleh sebagain besar sampel, antara lain sumber makanan tinggi lemak, akibat dari kurangnya asupan cairan, pengertian makanan selingan, apa yang dimaksud dengan anorexia nervosa dan gangguan asupan gizi. Sampel yang berpengetahuan gizi baik terdapat di Sastra Inggris Undip sebanyak 4 sampel dari keseluruhan sampel. Pengetahuan gizi yang dimiliki mahasiswi Sastra Inggris Undip lebih baik daripada pengetahuan gizi yang dimiliki mahasiswi LPP Graha Wisata Semarang. Secara statistik, terdapat perbedaan tingkat pengetahuan gizi antara 2 kelompok sampel $(\mathrm{p}=0,048)$.

Table 3. Skor Pengetahuan Gizi Sampel Penelitian

\begin{tabular}{cccc}
\hline Pengetahuan Gizi & $\begin{array}{c}\text { LPP Graha Wisata } \\
(\mathrm{n}=25)\end{array}$ & $\begin{array}{c}\text { Sastra Inggris } \\
(\mathrm{n}=25)\end{array}$ & $\mathrm{p}$ \\
\hline Baik & $0(0 \%)$ & $4(16 \%)$ & \\
Cukup & $8(32 \%)$ & $9(36 \%)$ & \\
Kurang & $17(68 \%)$ & $12(48 \%)$ & \\
Rerata Pengetahuan Gizi & $7,8 \pm 1,58$ & $9,08 \pm 2,05$ & 0,048 \\
\hline
\end{tabular}

\section{Sikap}

Penilaian sikap sampel dinilai dari jawaban sampel untuk menjawab kuesioner dengan nilai jawaban 1 sampai dengan 5. Sebagian besar sampel tidak mendukung sikap terhadap asupan zat gizi. Dari 50 sampel ada 13 sampel yang mendukung sikap terhadap asupan zat gizi, 5 sampel berada di LPP Graha Wisata Semarang dan
8 sampel berada di Sastra Inggris Undip. Skor sikap yang dimiliki mahasiswi LPP Graha Wisata Semarang antara 40 - 53 sedangkan di Sastra Inggris Undip antara 41 - 53. Secara statistik, tidak terdapat perbedaan sikap terhadap asupan zat gizi antara mahasiswi LPP Graha Wisata Semarang dan Sastra Inggris Undip $(p=0,396)$.

Table 4. Perbedaan Sikap Sampel Penelitian

\begin{tabular}{cccc}
\hline Sikap & $\begin{array}{c}\text { LPP Graha Wisata } \\
(\mathrm{n}=25)\end{array}$ & $\begin{array}{c}\text { Sastra Inggris } \\
(\mathrm{n}=25)\end{array}$ & $\mathrm{p}$ \\
\hline Mendukung & $5(20 \%)$ & $8(32 \%)$ & \\
Tidak mendukung & $20(80 \%)$ & $17(68 \%)$ & \\
Rerata Skor Sikap & $47,8 \pm 2,85$ & $46,8 \pm 3,98$ & 0,396 \\
\hline
\end{tabular}

\section{Asupan Zat Gizi}

Tabel 5 menggambarkan asupan zat gizi diantara dua kelompok sampel. Berdasarkan hasil recall $3 \times 24$ jam, asupan energi diantara 2 kelompok memiliki tingkat asupan energi yang defisit. Rerata TKE sampel LPP Graha Wisata lebih tinggi $(75,4 \%)$ dibanding Sastra Inggris Undip (69,9\%).

Table 5. Perbedaan Tingkat Kecukupan Asupan Zat Gizi

\begin{tabular}{lccccc}
\hline \multicolumn{1}{c}{\begin{tabular}{c} 
Rerata Tingkat $\begin{array}{c}\text { Kecukupan Asupan } \\
\text { Zat Gizi }\end{array}$ \\
\cline { 2 - 6 }
\end{tabular}} & $\begin{array}{c}\text { LPP Graha Wisata } \\
\text { Semarang } \\
(\mathrm{n}=25)\end{array}$ & $\begin{array}{c}\text { Sastra Inggris Undip } \\
(\mathrm{n}=25)\end{array}$ & \\
\cline { 2 - 6 } & Mean \pm SD & \% AKG & Mean \pm SD & $\%$ AKG & $\mathrm{p}$ \\
\hline $\begin{array}{l}\text { Tingkat Energi } \\
\text { (kkal) }\end{array}$ & $1240,9 \pm 298,9$ & 75,4 & $1263,4 \pm 239,8$ & 69,9 & 0,77 \\
\hline Tingkat Lemakn $(\mathrm{g})$ & $40,6 \pm 15,4$ & 87,9 & $42,6 \pm 14,2$ & 84,7 & 0,63 \\
\hline Tingkat Protein $(\mathrm{g})$ & $40 \pm 11,8$ & 70,4 & $39,2 \pm 9,5$ & 57,2 & 0,78 \\
\hline Tingkat Serat $(\mathrm{g})$ & $6,3 \pm 2,4$ & 31,6 & $6,4 \pm 1,8$ & 31,9 & 0,44 \\
\hline Tingkat Cairan $(\mathrm{g})$ & $1620 \pm 159,3$ & 64,8 & $1317,3 \pm 194,4$ & 52,7 & 0,00 \\
\hline
\end{tabular}


Table 6. Kategori Tingkat Asupan ?

\begin{tabular}{|c|c|c|}
\hline Kategori Tingkat Asupan Zat Gizi & $\begin{array}{l}\text { LPP Graha Wisata } \\
(n=25)\end{array}$ & $\begin{array}{c}\text { Sastra Inggris } \\
(\mathrm{n}=25)\end{array}$ \\
\hline \multicolumn{3}{|l|}{ Kategori Asupan Energi } \\
\hline Baik & $1(4 \%)$ & $0(0 \%)$ \\
\hline Sedang & $10(40 \%)$ & $10(40 \%)$ \\
\hline Kurang & $3(12 \%)$ & $2(8 \%)$ \\
\hline Defisit & $11(44 \%)$ & $13(52 \%)$ \\
\hline \multicolumn{3}{|l|}{ Kategori Asupan Lemak } \\
\hline Baik & $11(44 \%)$ & $9(36 \%)$ \\
\hline Sedang & $2(8 \%)$ & $5(20 \%)$ \\
\hline Kurang & $2(8 \%)$ & $3(12 \%)$ \\
\hline Defisit & $10(40 \%)$ & $8(32 \%)$ \\
\hline \multicolumn{3}{|l|}{ Kategori Asupan Protein } \\
\hline Baik & $4(16 \%)$ & $0(0 \%)$ \\
\hline Sedang & $2(8 \%)$ & $1(4 \%)$ \\
\hline Kurang & $1(4 \%)$ & $8(28 \%)$ \\
\hline Defisit & $18(72 \%)$ & $17(68 \%)$ \\
\hline \multicolumn{3}{|l|}{ Kategori Asupan Serat } \\
\hline Baik & $0(0 \%)$ & $0(0 \%)$ \\
\hline Sedang & $0(0 \%)$ & $0(0 \%)$ \\
\hline Kurang & $0(0 \%)$ & $0(0 \%)$ \\
\hline Defisit & $25(100 \%)$ & $25(100 \%)$ \\
\hline \multicolumn{3}{|l|}{ Kategori Asupan Cairan } \\
\hline Baik & $0(0 \%)$ & $0(0 \%)$ \\
\hline Sedang & $1(4 \%)$ & $0(0 \%)$ \\
\hline Kurang & $4(16 \%)$ & $0(0 \%)$ \\
\hline Defisit & $20(80 \%)$ & $25(100 \%)$ \\
\hline
\end{tabular}

Tingkat kecukupan asupan lemak antara kedua kelompok sampel sama baiknya. Namun berdasarkan Tabel 5, sampel yang berada di LPP Graha Wisata Semarang $(87,9 \%)$ tingkat asupan lemak lebih baik daripada sampel yang berada di Sastra Inggris Undip (84,7\%). Pada tingkat asupan protein, untuk kedua kelompok sampel berbeda. Namun mahasiswi LPP Graha Wisata Semarang $(70,4 \%)$ lebih baik daripada tingkat asupan protein mahasiswi Sastra Inggris Undip (57,2\%). Berdasarkan Tabel 6 terdapat 4 sampel di LPP Graha Wisata Semarang yang memiliki tingkat asupan protein baik. Tingkat kecukupan asupan serat dan cairan tidak berbeda jauh. Kedua kelompok sampel memiliki asupan serat dan cairan yang tergolong defisit. Asupan serat sampel yang berada di Sastra Inggris Undip $(31,6 \%)$ tidak berbeda jauh dari sampel yang berada di LPP Graha Wisata Semarang (31,9\%), sedangkan tingkat asupan cairan untuk mahasiswi LPP Graha
Wisata Semarang $(64,8 \%)$ lebih baik daripada mahasiswi Sastra Inggris Undip (52,7\%).

Hasil uji independent t-test untuk asupan energi, protein, lemak dan cairan, sedangkan uji mann whitney untuk asupan serat. Hasil uji menyatakan bahwa terdapat perbedaan tingkat asupan cairan antara kedua kelompok sampel $(\mathrm{p}=$ 0,00 ), untuk tingkat asupan energi, lemak, protein dan serat tidak terdapat perbedaan $(\mathrm{p}=0,77 ; \mathrm{p}=$ $0,63 ; p=0,78 ; p=0,44)$.

\section{PEMBAHASAN \\ Pengetahuan Gizi}

Pengetahuan gizi adalah ilmu yang mempelajari semua hal tentang gizi. Pengetahuan untuk memilih makanan yang patut dikonsumsi atau tidak, perlu dimiliki oleh setiap individu. ${ }^{6}$ Pengetahuan gizi dapat dipengaruhi beberapa hal, salah satunya adalah pendidikan mengenai gizi. ${ }^{13,16}$ Dalam penelitian ini, sebagian besar sampel mempunyai pengetahuan gizi yang kurang, hal ini 
mungkin dikarenakan mereka kurang memahami informasi yang diberikan baik secara sosial atau media masa yang berhubungan dengan makanan. Hal lain yang mungkin menyebabkan sampel mempunyai pengetahuan gizi yang kurang adalah kedua kelompok sampel tidak menerima pendidikan mengenai gizi di tempat perkuliahan. Mahasiswi LPP Graha Wisata diharapkan lebih memahami pengetahuan tentang gizi karena diketahui bahwa pada perkuliahan, penampilan adalah hal terpenting, sehingga pengetahuan tentang gizi dapat mempengaruhi mereka untuk mengkonsumsi makanan yang bergizi. Keadaan ini sama dengan penelitian sebelumnya tahun 2011 pada mahasiswa di Amerika sebanyak 68,4\% mempunyai pengetahuan gizi yang kurang. Ini menunjukkan bahwa mahasiswa yang tidak diberikan pendidikan mengenai gizi, pengetahuan gizinya rendah. ${ }^{19}$

Secara statistik terdapat perbedaan pengetahuan gizi antara mahasiswi LPP Graha Wisata Semarang dan mahasiswi Sastra Inggris Undip, dan sampel yang berada di Sastra Inggris Undip mempunyai pengetahuan gizi yang lebih baik daripada sampel yang berada di LPP Graha Wisata Semarang dengan skor tingkat pengetahuan yang tidak jauh berbeda $46,2 \%$ dan $53,8 \%$. Seseorang dengan pendidikan tinggi diharapkan luas pula pendidikannya dalam hal ini mengenai gizi. Informasi yang diperoleh baik dari pendidikan formal maupun non formal dapat memberikan pengaruh jangka pendek (immediate impact) sehingga menghasilkan perubahan atau peningkatan pengetahuan tentang gizi. ${ }^{12,13,16}$ Dengan adanya pengetahuan gizi, seseorang menjadi tahu apa yang seharusnya mereka makan dan tidak seharusnya mereka makan, sehingga pengetahuan gizi dapat mempengaruhi sikap manusia terhadap makanan.

\section{Sikap}

Sikap dalam penelitian ini adalah cara pemahaman individu terhadap makanan atau asupan zat gizi yang diwujudkan melalui suatu tindakan. Sikap yang mereka tunjukkan kurang mendukung. Sebanyak 13 (26\%) sampel dari 50 sampel yang mendukung sikap terhadap asupan zat gizi dan 37 (74\%) sampel tidak mendukung sikap terhadap asupan zat gizi. Hal ini mungkin dikarenakan, kurangnya pengetahuan mereka terhadap makanan atau asupan zat gizi. Walaupun pengetahuan gizi mahasiswi Sastra Inggris lebih baik daripada mahasiswi LPP Graha Wisata, namun belum tercermin dalam sikap mereka. Penelitian ini juga sesuai dengan penelitian pada mahasiswa UNJ menunjukkan bahwa pengetahuan dapat mempengaruhi sikap mahasiswa terhadap asupan zat gizi. ${ }^{20}$ Hal lain yang mempengaruhi sikap mereka pada penelitian ini adalah tempat, waktu dan uang. Karena terbatasnya waktu membuat mereka cederung malas untuk mencari makanan yang bervariasi. Tempat makan yang terdekat dan murah menjadi andalan konsumsi makan mereka. Padahal belum tentu makanan yang dijual di warung yang terletak dekat dengan rumah atau kos-kosan dan harganya murah itu sehat dan bergizi.

\section{Asupan Zat Gizi}

Asupan makanan adalah informasi tentang jumlah dan jenis makanan yang dimakan atau dikonsumsi oleh seseorang atau kelompok orang pada waktu tertentu. ${ }^{21}$ Dalam penelitian ini, recall asupan makanan berasal dari makanan dan minuman yang dikonsumsi oleh sampel. Berdasarkan hasil recall $3 \times 24$ jam menunjukkan bahwa dari keseluruhan sampel terdapat 24 sampel mempunyai asupan energi devisit dan lebih banyak di Sastra Inggris.

Manusia membutuhkan energi untuk mempertahankan hidup guna menunjang pertumbuhan dan melakukan aktivitas harian. Berdasarkan penelitian sebelumnya, bahwa asupan zat gizi dipengaruhi oleh faktor ekonomi, aktivitas fisik $^{22}$ dan gaya hidup. ${ }^{23}$ Kesibukan mereka sebagai mahasiswi menyebabkan mereka lupa waktu untuk makan, sehingga rata-rata sampel mempunyai asupan gizi yang defisit. Hal lain yang mungkin menyebabkan kurangnya asupan energi adalah penyediaan makanan di rumah. Berdasarkan data yang diperoleh tentang penyediaan makanan, sebagian besar sampel menjawab asupan makanan disediakan dirumah oleh ibu, dan hanya beberapa sampel menjawab makanan diperoleh dengan cara membeli dan memasak sendiri. Asupan zat gizi yang tidak seimbang antara zat gizi yang masuk ke dalam tubuh dan yang digunakan untuk keperluan proses pertumbuhan, aktivitas dan lainnya berlangsung dalam jangka waktu yang lama akan menimbulkan masalah kesehatan. Mahasiswi ikut berperan sebagai sumber daya manusia yang produktif bagi suatu negara. Menurunnya kualitas sumber daya manusia disuatu negara dapat menurunkan kualitas suatu negara. ${ }^{24}$

Akibat kurang gizi terhadap proses tubuh bergantung pada zat-zat gizi apa yang kurang. Kekurangan gizi secara umum (baik kuantitas maupun kualitas) menyebabkan gangguan pada proses - proses pertumbuhan, produksi tenaga berkurang menyebabkan produktivitas kerja 
menurun, daya tahan tubuh menurun sehingga mudah terserang virus, kemampuan berpikir menurun, dan terjadi perubahan perilaku menjadi tidak tenang dan mudah tersinggung. ${ }^{25}$

Pada tingkat asupan lemak menunjukkan kategori baik lebih banyak di LPP Graha Wisata Semarang yaitu sebanyak $44 \%$ sampel daripada di Sastra Inggris Undip. Hal ini sesuai dengan tuntutan sebagai mahasiswi LPP GRaha Wisata, bahwa mereka diharapkan dapat menjaga penampilan mereka salah satunya dengan asupan lemak yang sesuai dengan kebutuhan. Berdasarkan interview terhadap asupan makanan yang berlemak, mereka banyak menjawab tidak begitu menghindari makanan berlemak, mereka makan seadanya. Sebagian besar sampel di LPP Graha Wisata Semarang mempunyai kebiasaan makan makanan selingan yang cara pembuatannya dengan digoreng, seperti tempe goreng, ayam goreng dan pisang goreng. Lemak yang dikonsumsi dengan jumlah yang sesuai dengan kebutuhan dapat membantu penyerapan vitamin larut lemak, menjadi sumber energi yang kedua setelah karbohidrat, memberi rasa kenyang dan lezat pada makanan, memelihara suhu tubuh dan sebagai pelindung organ tubuh. ${ }^{25}$ Penelitian sebelumnya, jika asupan lemak kurang dapat menghambat pertumbuhan dan gangguan fungsi organ tubuh. Sedangkan bila asupan lemak berlebih dapat menyebabkan kegemukan dan penyakit jantung koroner dan kanker. ${ }^{26}$

Tingkat asupan protein menunjukkan bahwa kategori devisit terdapat pada kedua kelompok. Hal ini dikarenakan asupan makanan yang kurang mencukupi kebutuhan gizi terutama makanan yang mengandung protein hewani. Protein hewani seperti ikan, daging, susu, dan telur jarang sekali dikonsumsi oleh mahasiswi di LPP Graha Wisata Semarang dan Sastra Inggris Undip. Sedangkan, asupan protein nabati seperti tahu, tempe dan kacang-kacangan sering dikonsumsi oleh sampel. Protein sebagai sumber energi ketiga setelah karbohidrat dan lemak, jika asupan protein tidak sesuai dengan kebutuhan tubuh akan berdampak pada fungsi tubuh. Hasil penelitian ini berbeda dengan hasil penelitian sebelumnya. Hasil penelitian sebelumnya menunjukkan bahwa asupan protein pada saat dewasa lebih tinggi berkisar antara $20-30 \%$ asupan protein per hari. ${ }^{27}$

Kurangnya asupan protein dapat menyebabkan terhambatnya pertumbuhan dan pemeliharaan sel-sel tubuh, pembentukan ikatanikatan esensial tubuh, mengatur keseimbangan air, memelihara netralitas tubuh, pembentukan antibodi dan mengangkut zat - zat gizi, serta bila dalam jangka waktu yang lama dapat menyebabkan KEP (Kekurangan Energi Protein).

Tingkat kecukupan serat dan cairan kedua kelompok menunjukkan hasil yang sama. Keseluruhan sampel dengan kategori devisit pada asupan serat dan 45 (90\%) sampel dengan kategori devisit pada asupan cairan. Hal ini dikarenakan, makanan sumber serat seperti buah-buahan dan sayuran jarang dikonsumsi oleh kedua kelompok sampel.

Menurut Sunita, anjuran kebutuhan serat sehari 20-30 gram, sedangkan rata-rata asupan serat kedua kelompok berkisar antara 6 gram sehari. ${ }^{8}$ Penelitian yang dilakukan pada mahasiswi bahwa terdapat hubungan antara kurangnya asupan serat terhadap gangguan fungsi sistem pencernaan tubuh dan dapat mengakibatkan meningkatnya kejadian kanker kolon. ${ }^{28,29}$

Tingkat asupan cairan kategori devisit lebih banyak di Sastra Inggris Undip daripada di LPP Graha Wisata Semarang. Hal ini dikarenakan, kurangnya kesadaran mereka akan asupan cairan. Rata-rata asupan cairan kedua kelompok berkisar antara $1300 \mathrm{ml}$ sampai dengan $1600 \mathrm{ml}$, sedangkan menurut Health and Nutrition Examination Survey III (NHANES III) menetapkan bahwa asupan cairan untuk wanita 2,5 liter air sehari, hal ini dikarenakan asupan cairan devisit dapat dipengaruhi oleh usia, pendidikan atau pengetahuan dan aktivitas fisik. Penelitian tahun 2006 pada orang Amerika bahwa asupan cairan pada orang dewasa baik laki-laki maupun perempuan adalah 3,18 liter. Tiga puluh tiga persen dari air mineral, $48 \%$ dari minuman olahan dan $18 \%$ dari makanan. ${ }^{30}$

Air mempunyai berbagai fungsi dalam proses vital tubuh, yaitu : (1) air sebagai pelarut dan alat angkut, air dalam tubuh berfungsi sebagai pelarut zat-zat gizi berupa monosakarida, asam amino, lemak, vitamin dan mineral serta bahanbahan lain yang diperlukan tubuh seperti oksigen dan hormon-hormon, (2) sebagai katalisator, air berperan sebagai katalisator dalam berbagai reaksi biologik dalama sel, termasuk didalam saluran cerna. Air diperlukan pula untuk memecah atau menghidrolisis zat gizi kompleks menjadi bentukbentuk lebih sederhana, (3) sebagai pelumas, air berperan sebagai pelumas dalam cairan sendi-sendi tubuh, (4) sebagai fasilitator pertumbuhan, air sebagai bagian jaringan tubuh diperlukan untuk pertumbuhan. Dalam hal ini air berperan sebagai zat pembangun, (5) sebagai pengatur suhu, karena kemampuan air untuk menyalurkan panas, air 
memegang peranan dalam mendistribusikan panas didalam tubuh, (6) sebagai peredam benturan, air dalam mata, jaringan saraf tulang belakang dan dalam kantung ketuban melindungi organ-organ tubuh dari benturan. Aktivitas tubuh akan selalu mengeluarkan cairan dalam bentuk keringat, urin, feses dan nafas.

Tubuh akan kehilangan cairan sekitar 2,5 liter setiap hari. Untuk menjaga agar kondisi dan fungsi cairan tubuh tidak terganggu, kehilangan tersebut harus diganti. Jika tubuh tidak cukup mendapat air atau kehilangan air sekitar 5\% dari berat badan (pada anak, remaja dan dewasa) maka keadaan ini telah membahayakan kehidupan seseorang atau dikenal sebagai dehidrasi berat. Dehidrasi akan mengakibatkan menurunnya volume plasma sehingga menimbulkan gangguan termoregulasi dan kerja jantung. Selanjutnya akan mempengaruhi kinerja tubuh secara keseluruhan. Dehidrasi juga menurunkan kemampuan sistem kardiovaskuler dan pengaturan suhu tubuh. Dehidrasi berat menyebabkan kerja otak terganggu sehingga cenderung mengalami halusinasi. ${ }^{31}$

\section{SIMPULAN}

Sebagian besar sampel mempunyai pengetahuan gizi yang kurang, hanya empat sampel yang mempunyai pengetahuan gizi yang baik terdapat di Sastra Inggris Undip. Sebagian besar sampel mempunyai sikap yang tidak mendukung asupan makan yang baik. Terdapat perbedaan pengetahuan gizi $(\mathrm{p}=0,048)$ antara mahasiswi LPP Graha Wisata Semarang dan mahasiswi Sastra Inggris Undip, namun tidak terdapat perbedaan sikap $(\mathrm{p}=0,396)$ antara kedua kelompok sampel.

Sebagian besar sampel mempunyai asupan zat gizi yang kurang antara lain asupan energi, protein, serat dan cairan, sedangkan asupan lemak kedua kelompok sampel termasuk cukup. Rerata keseluruhan tingkat kecukupan asupan zat gizi mahasiswi LPP Graha Wisata lebih baik daripada mahasiswi Sastra Inggris Undip. Tidak terdapat perbedaan asupan energi $(\mathrm{p}=0,771)$, lemak $(\mathrm{p}=0,628)$, protein $(\mathrm{p}=0,778)$ dan serat $(\mathrm{p}=0,438)$, tetapi terdapat perbedaan asupan cairan $(\mathrm{p}=0,00)$.

\section{SARAN}

1. Perlu adanya peningkatan pengetahuan gizi dan pemahaman tentang asupan zat gizi baik melalui pendidikan formal maupun non formal sehingga dapat mewujudkan perilaku makan yang baik.
2. Perlu adanya peningkatan asupan serat dan cairan dengan jumlah sesuai dengan kebutuhan masing-masing individu.

\section{DAFTAR PUSTAKA}

1. Kimberly M. Nutrition in the Adult Years. In: Mahan K, Escott-Stump S. Krause's food, Nutrition and Diet Therapy. $11^{\text {th }}$ edition. Philadelphia: Saunders; 2004: p.22; 24; 303.

2. Agoes Dariyo. Psikologi Perkembangan Dewasa Muda. Jakarta : PT. Gramedia Widiasarana Indonesia : 2003.

3. Arya P. Pengertian Remaja Menurut Para Ahli. [Online]. 11 Maret 2010. [dikutip pada tanggal 31 Maret 2011]. Tersedia dari: http://belajarpsikologi.com/pengertian-remaja/

4. Erna Franein P. Gizi dalam Kesehatan Reproduksi. Jakarta: EGC; 2004: hal: 7.

5. Marie EB. At-a-Glance Ilmu Gizi. Jakarta: Erlangga; 2009.

6. Soekidjo Notoatmojo. Promosi Kesehatan dan Ilmu Perilaku. Jakarta: Rineka Cipta; 2007.

7. Judith L. Dodd. Nutrition in the Adult. Krause Food and Nutrition Therapy. Philadelphia, USA: Saunders; 2008; p. 270.

8. Sunita Almatsier. Penuntun Diet. Jakarta : Gramedia Pustaka Utama; 2007. Hal : 12.

9. Fatma Zuhrotun N. Korelasi Antara Asupan Makanan, Tingkat Pengetahuan Gizi, Pelayanan Kesehatan dan Sanitasi Lingkungan Dengan Status Gizi Di Pesantren X Yogyakarta. [Online]. 3 Agustus 2007. [dikutip pada tanggal 9 November 2011]. Tersedia dari: http://fatmanisa.wordpress.com/

10. Catherine G, Hilary P. Human Nutrition Eleven Edition. New York: Edinburgh; 2005: p. 10-6.

11. Pramadavita Andini. Hubungan Pengetahuan Gizi dengan Asupan Zat Gizi Makro dan Mikro Mahasiswa Program Studi Ilmu Gizi FK UNDIP. [Skripsi]. Program Studi Mahasiswa Ilmu Gizi FK UNDIP; 2010.

12. Hastri Royyani. Pentingnya Pengetahuan Gizi bagi Masyarakat. [Online]. 19 Maret 2010. [dikutip pada tanggal 20 November 2010]. Tersedia dari: http://www.itb.ac.id/news/2754.xhtml

13. Dunia Baca. Definisi Pengetahuan dan Faktorfaktor yang mempengaruhi Pengetahuan. [Online]. 17 April 2010. [dikutip pada tanggal 4 Desember 2011]. Tersedia dari http://duniabaca.com/definisi-pengetahuan-sertafaktor-faktor-yang-mempengaruhipengetahuan.html

14. Nanik Kristianti. Hubungan Pengetahuan Gizi dan Frekuensi Konsumsi Fast Food dengan Status Gizi Siswa SMA Negeri 4 Surakarta. [Online]. 8 Oktober 2009. [dikutip pada tanggal 26 Maret 2011]. Tersedia dari : http://etd.eprints.ums.ac.id/4021/1/J310040004.pdf 
15. Lawrence E. Green. Educational and Organization Diagnosis: Factor Affecting Health-Related Behaviour and Environtments. In Health Promotion Planning. USA: Mayfield Publishing Company; 1991.

16. Isobel R. Contento. Nutrition Education. Canada: Jones and Barlett Publisher; 2007.

17. Khomsan A. Teknik Pengukuran Pengetahuan Gizi. Bogor: IPB; 2000: 30; 34.

18. Saifuddin Azwar. Sikap Manusia Teori dan Pengukurannya. Yogyakarta: Pustaka Pelajar; 2009.p. 156.

19. Douglas L. T. Effect of an integrated nutrition curriculum on medical education, student clinical performance, and student perception of medicalnutrition training. Am J Clin Nutr 2001;73:110712.

20. Rahma Boedi. Sikap Mahasiswa Terhadap Pemenuhan Gizi Seimbang. [Online] Universitas Negeri Jakarta. 2001. [dikutip pada tanggal 9 Juni 2012]. Tersedia dari : http//: sikap-mahasiswaterhadap-pemenuhan-gizi-seimbang.html

21. Maretha Resnaeny P. Perbedaan Tingkat Asupan Energi, Protein, dan Status Gizi Anak Asuh di Panti Asuhan Desa dan Kota. Mahasiswa Program Studi Ilmu Gizi FK UNDIP. [Skripsi]. Program Studi Mahasiswa Ilmu Gizi FK UNDIP; 2009.

22. Amy Luke. Activity energy expenditure and adiposity among black adults in Nigeria and the United States. Am J Clin Nutr 2002;75:1045-50.

23. Kopertis IV. Konsep Dasar Timbulnya Masalah Gizi. [Online]. Dosen Sekolah Tinggi Ilmu Kesehatan Cimahi. [dikutip pada tanggal 25 Mei 2012]. Tersedia dari : http//: konsep-dasartimbulnya-masalah-gizi.html

24. PK Newby. Food patterns measured by factor analysis and anthropometric changes in adults. Am J Clin Nutr 2004;80:504-13.

25. Sutrisno Koswara. Konsumsi Lemak Yang Ideal Bagi Kesehatan. [Online]. [dikutip pada tanggal 4 Desember 2011]. Tersedia dari : http//: ebookpangan.com.

26. Na Zhu. Fat mass modifies the association of fatfree mass with symptom-limited treadmill duration in the Coronary Artery Risk Development in Young Adults (CARDIA) Study. Am J Clin Nutr 2011;94:385-91.

27. Jane E Kerstetter. Dietary protein, calcium metabolism, and skeletal homeostasis revisited. Am J Clin Nutr 2003;78(suppl):584S-92S.

28. Huaidong Du. Dietary fiber and subsequent changes in body weight and waist circumference in European men and women. Am J Clin Nutr 2010;91:329-36.

29. Praseptia Gardiarini. Hubungan Antara Asupan Serat, Asupan Cairan dan Aktifitas Fisik Terhadap Kejadian Konstipasi. [Skripsi]. Mahasiswa Program Studi Ilmu Gizi FK UNDIP; 2010.
30. Ashima K Kant. Intakes of plain water, moisture in foods and beverages, and total water in the adult US population-nutritional, meal pattern, and body weight correlates: National Health and Nutrition Examination Surveys 1999-2006. Am J Clin Nutr 2009;90:655-63.

31. Yuniastuti, Ari. Gizi dan Kesehatan. Yogyakarta. Graha Ilmu. 2008. 